\title{
Food Habits of Schilbe Intermedius, Rüppel, 1832 (Siluriformes: Schilbeidae) of Right Bank of Pool Malebo(Congo River)
}

\author{
Mady-Goma Dirat I. ${ }^{1 *}$, Olabi Obath B.R.C. ${ }^{1,2}$, Tsoumou A. ${ }^{1}$, Mikia M. ${ }^{1}$, Vouidibio J. ${ }^{2}$ \\ ${ }^{1}$ Research Laboratory of Animal Biology and Ecology, ENS, University Marien Ngouabi, PoBox 69 \\ Brazzaville, Congo \\ ${ }^{2}$ Faculty of Sciences and Techniques, University Marien Ngouabi, PoBox 69, Brazzaville, Congo
}

*Corresponding Author: Mady-Goma Dirat I., Research Laboratory of Animal Biology and Ecology, ENS, University Marien Ngouabi, PoBox 69 Brazzaville, Congo

\begin{abstract}
The diet of Schilbe intermedius of the right bank of Pool-Malebo (Congo Brazzaville) was studied by examining the stomach contents of 942 individuals captured using the cash nets. Three stations were sampled monthly from January 2010 to December 2011. The analysis covered individuals with a standard length ranging from 23.93 to $129.3 \mathrm{~mm}$ according to sampling stations, hydrological season and fish size. . The preponderance index combining the numerical occurrence percentage and the weight percentage was calculated. The percentage of emptiness is $27 \%$, fishes are the main preys consumed by Schilbe intermedius with a preponderance index equal to $64 \%$. There was variation in diet according to the season and the specimens size. The correlation coefficient of Spearman showed that the proportions of the different foods vary according to the size of the specimens ( $r s=0.42, p=0.05)$. Schilbe intermedius is insectivorous in small juveniles that are becoming piscivorous predators in older, larger specimens.
\end{abstract}

Keywords: Congo River, Feeding habits, Schilbe intermedius, preponderance index, Schoener index

\section{INTRODUCTION}

The knowledge of fish feeding in the wild is an essential step in understanding their biology and ecology. The knowledge of the ingested prey as well as that of the fish's feeding habits are essential to understand their place and their function in the ecosystem (1). The study of fish feeding can provide data, not only on the presence of prey, but also on the abundance and availability of the trophic potential of the environment. In addition, it helps to understand the relationships between fish and prey, as well as interspecific relationships (2). The knowledge of the diet of a fish allows to define its ecological niche and by extension its habitat. The analysis of stomach contents makes it possible to determine the composition of the diet and to appreciate the use of the food available in the environment. The knowledge of fish preferences and the strategies used to colonize habitats are important data in conservation and sustainable management strategies for stocks (3).

Schilbe intermedius, commonly known as silver catfish, is a species of catfishof the family Schilbeidae prized for the quality of its meat organoleptic point of view (4)and its abundance in catches on the Congo River(5).In addition, the Schilbeidae are one of the groups of freshwater and brackish water fish economically more important worldwide [6].This species is widespread in most of Africa, absent in North Africa and South Africa(7).Despite the global economic importance of Schilbe(8).Enormous literature exist on the food and the feeding habits of the fish in most inland water bodies, manyinvestigations on the diet of this type of fish $(9,10,11,12,13,14,15,16,17,18$, $19,20,21,22,23)$,have been undertaken in West Africa and South Africa. No dietary studies in Schilbe intermediushave been carried out in the Congo Basin, so to fill this gap, we have undertaken the study of the diet of this species according to the season, the station and the size.

\section{Materials ANd Methods}

\subsection{Study Area}

The Schilbe intermedius diet was sampled in three stations on the right bank of the Pool Malebo (Figure 1). The three stations were investigated each month from January 2010 to December 2011. Kintele station or Station 1 is located between $04^{\circ} 12.745^{\prime}$ south, $015^{\circ} 15.064$ East and $04^{\circ} 08.967^{\prime}$ 
south, $015^{\circ} 21.909$ 'East longitude. This station is located between the Congo River confluence and Ngapouyi waterway and Kintele village in front of Faignond Island. Chacona station or Station 2 has the following geographical location: $04^{\circ} 17.006$ 'South, $015^{\circ} 16.350^{\prime}$ East and $04^{\circ} 16.655^{\prime}$ South and $015^{\circ} 17.006^{\prime}$ East. This station is located between the confluence Congo River and Tsieme River and the thermal power station of Mpila. In some places, there is very little vegetation dominated by Echinochloa stagnina, Echornia crassipes and Hypomea aquatica. Port Leon station or Station 3 is positioned between $04^{\circ} 14.860^{\prime}$ South latitude $-015^{\circ} 18.352^{\prime}$ East longitude and $04^{\circ} 14$. $352^{\prime}$ South latitude $015^{\circ} 18.102^{\prime}$ East. This station is located between the ATC port and the Chad ravine where the rest of the vegetable belt of Brazzaville is observed.

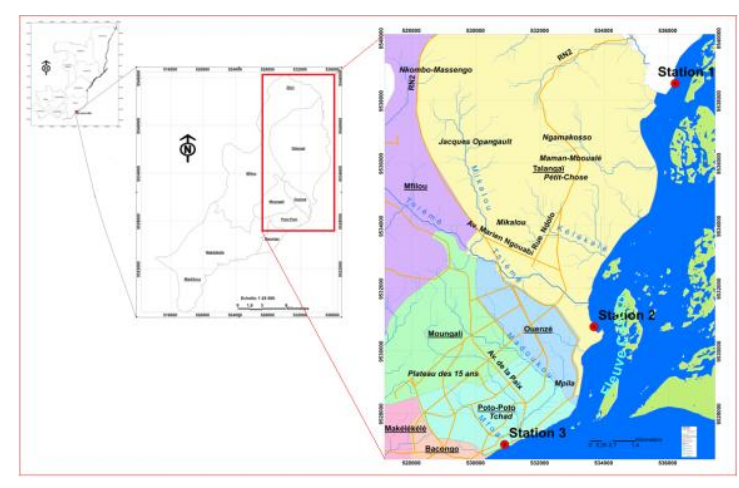

Figure1. Study area

The distribution of numerical abundance of specimens by station and sampling period is summarized in Table 1.

Table1. Spatio-temporal repartition of numerical abundance of Schilbe intermedius

\begin{tabular}{|l|c|c|c|c|c|c|}
\hline Stations & \multicolumn{2}{|c|}{ Kintélé Station } & \multicolumn{2}{c|}{ Chacona Station } & \multicolumn{2}{c|}{ Port Léon Station } \\
\hline Seasons & Rainy Season & Dry Season & Rainy Season & Dry Season & Rainy Season & Dry Season \\
\hline $\begin{array}{l}\text { Numerical } \\
\text { abundance }\end{array}$ & 143 & 113 & 177 & 58 & 254 & 185 \\
\hline
\end{tabular}

\subsection{Intestinal Coefficient}

The intestinal coefficient (IC) was calculated for each individual according to the following formula (8):

$$
\begin{aligned}
& \mathrm{IC}=\frac{\mathrm{IL}}{\mathrm{SL}} \\
& \mathrm{IL}=\text { Intestine length; } \\
& \mathrm{SL}=\text { Standard length }
\end{aligned}
$$

This coefficient allows to determine predictably the trophic guilds.

\subsection{Analysis of Stomach Contents}

The study of the fish diet often includes two types of analysis: qualitative analysis and quantitative analysis (24). Qualitative analysis which consists in drawing up a complete list of the different preys encountered in the stomachs, followed by quantitative analysis which specifies the importance different preys and highlights the possible variations of the diet according to the in dividuals size and the season.

\subsection{Coefficient of Emptiness (CE)}

Coefficient of emptinessis the ratio expressed as a percentage between the empty stomachs number and the total number of full stomachs examined:

$\mathrm{CE}=\frac{\mathrm{E}_{\mathrm{s}}}{\mathrm{N}_{\mathrm{T}}} \times 100$

Es = empty stomachs number;

$\mathrm{NT}=$ total number of full stomachs examined. 


\subsection{Degree of Presence or Percentage of Occurrence (OC)}

It is the only dietary index used to analyze the diet results of this species (2), it is given by the following formula:

$\mathrm{OC}=\frac{\mathrm{n}_{\mathrm{i}}}{\mathrm{N}_{\mathrm{T}}} \times 100$

$\mathrm{ni}=$ number of stomachs containing a category of prey $\mathrm{i}$;

NT $=$ total number of full stomachs examined.

\subsection{Preponderance Index}

To quantify the relative importance of prey, the following indices were calculated (15): percentage of occurrence (normalized to 100) and weight percentage (25). To avoid bias in the use of these indices, the preponderance index (26) that incorporates these two indices has been determined:

$\mathrm{Ip}=\frac{\% \mathrm{Oc} x \% \mathrm{P}}{\sum(\% \mathrm{Oc} \times \mathrm{P})} \times 100$

$\%$ OC $=$ Percentage of occurrence;

$\% \mathrm{~W}=$ Weight percentage;

Ip $=$ Preponderance index.

The different types of preys are ranked according to the value of the preponderance index as follows:

Ip $\leq 10$ : accessory preys;

$10<$ Ip $<25$ : secondary preys;

$<$ Ip <50: important preys;

Ip $\geq 50$ : main preys.

\subsection{Schoener Index}

The calculation of Schoener index (27) made it possible to evaluate the degree of similarity of the diet between stations, seasons and sexes, it is given by the relation:

$\alpha=1-0,5\left(\sum_{\mathrm{i}=1}^{\mathrm{n}}\left|\mathrm{P}_{\mathrm{xi}}-\mathrm{P}_{\mathrm{yi}}\right|\right)$

Pxi $=$ proportion of preys consumed by individuals of a season $\mathrm{x}$;

Pyi $=$ proportion of preys consumed by individuals in a season $\mathrm{y}$.

Diets are considered significantly similar when the value of $\alpha$ is greater than or equal to 0.6 (28).

\subsection{Statistical Analyzes}

A Cluster analysis based on Euclidean distance is performed from matrix the preys occurrence classes sizes, to identify the similarities between diets of individuals at different sizes. The combination of monthly results in two hydrological seasons makes it possible to determine seasonal variations in the diet of the species studied

\section{RESULTS AND DISCUSSION}

\subsection{Description of the External Morphology of the Digestive Tract of Schilbe Intermedius}

The digestive tract of Schilbe intermedius has an esophagus followed by a thick-walled stomach, 3 unequal size pyloric caeca and a short intestine (Figure 2).

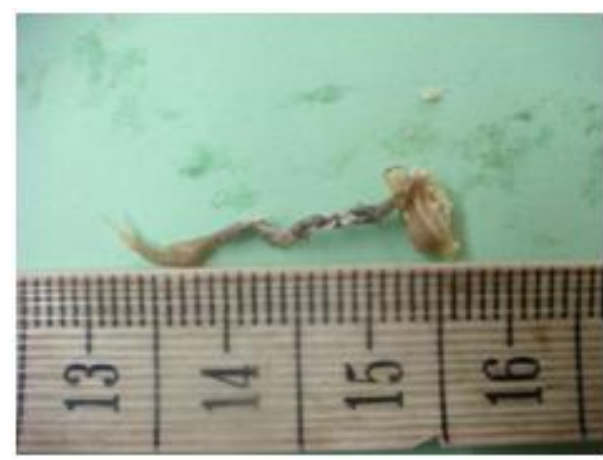

Figure2. Digestive tract of $S$. intermedius 


\subsection{Intestinal Coefficient of Schilbe Intermedius}

The intestinal coefficient of Schilbe intermedius varies between 0.18 and 1.42 , with an average of $0.55 \pm 0.16$ (Figure 3). This value of the intestinal coefficient less than 3 shows that the intestine is short, indicating that this species is omnivorous $(8 ; 29)$. The correlation between standard length and the intestinal length is quite good because the coefficient of determination $\mathrm{r} 2$ is equal to 0.65 and the correlation coefficient $r$ equal to 0.8 (Figure 4).

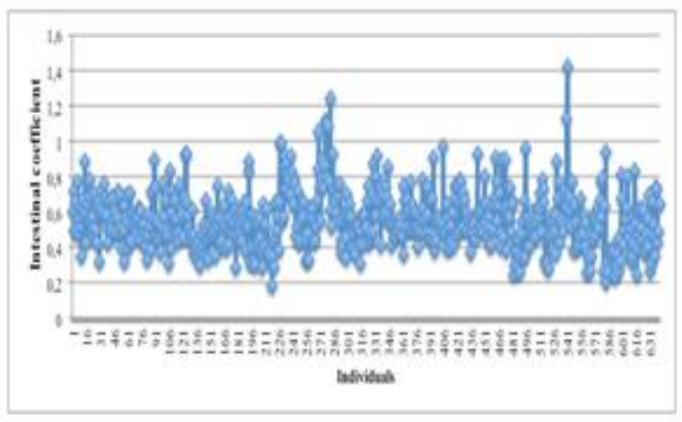

Fig3. Intestinal coefficient of S. intermedius

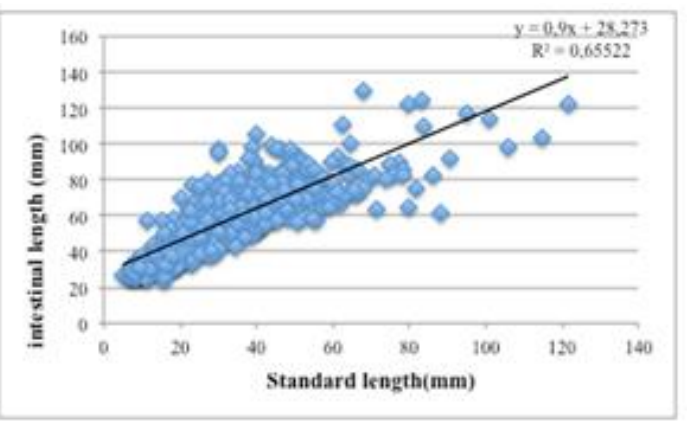

Fig4.Relation between intestinal length and the standard length of $S$. intermedius

\subsection{Coefficient of Emptiness}

The number of empty stomachs was 258 for a total of $942 \mathrm{~S}$. intermedius individuals examined, representing a emptiness coefficient of 27\%. At Kintélé, 69 stomachs out of 214 examined were empty, giving a emptiness coefficient of 32\%. The number of empty stomachs at Chacona was 69 out of a total of 235 , which corresponds to a emptiness coefficient of $25 \%$. At Port Leon, the emptiness coefficient was $27 \%$.

\subsection{Global Composition of Trophic Structures}

The overall composition of the trophic structures of Schilbe intermedius of Pool Malebo (Table 2 ), shows that fishes had the highest occurrence of 34\%, followed by plant debris (14\%), unidentified insects $(13 \%)$, unidentified preys $(11 \%)$, trichoptera larvaes, sand grains and beetle larvaes $(8 \%)$, diptera (6\%). Other preys had an occurrence between 3\% and $0 \%$ (Table 2). Overall, fishes were the main preys consumed by Schilbe intermedius with a preponderance index equal to 64\%; insects $(13,17 \%)$, others preys $(11,88 \%)$, plant debris $(10,48 \%)$ are the secondary preys and others animal preys are accessory preys. The analysis of the general trophic structure of Schilbe intermedius on the right bank of the Malebo Pool (Congo River) showed that this species is omnivorous, a result in accordance with the length of the intestine which is less than 3.Many authors have obtained similar results showing that the diet of this species still includes fishes, insects and plants debris.Carey (30) has shown that $\mathrm{S}$. intermedius of Kafue flood plain are partially piscivorous; they also eat insects, crustaceans and plant debris.Reynolds (22), who studied the diet of Schilbe intermedius in the Volta Basin, showed that specimens larger than $100 \mathrm{~mm}$ eat more ephemeroptera, fish and a few terrestrial insects. Results obtained by Mok (18) showed that the diet of Schilbe intermedius in the lake Chad basin is also composed mainly of fishes ( $80 \%$ to $90 \%$ of the total weight). The occurrence of aquatic insects was equal to $39.2 \%$ by volume and $25 \%$ of ostracodes. Olatunde (21) in lake Kainji, found also results close to those of the right bank of the Malebo Pool.In this lake, fishes and insects (adult beetles, orthopterans, odonate nymphs) were consumed; fishes were the most important preys item with 63\%. This species consumes mainly fishes $(15,16,17,19,20,31,32,33)$, Cichlidae and Cyprinidae are mainly preys of S. intermedius. Others fisheslike the genus Synodontis serve as preys (23). Welcomme (34) described this speciesas a meso-predator with a diet composed of crustaceans and insects.

Table2. Composition of Schilbe intermedius diet in Pool Malebo Oc $=\%$ occurrence; $\% P=$ weight percentage; I $=$ preponderance index

\begin{tabular}{|c|c|c|c|}
\hline Preys & \% Oc & \%P & Ip \\
\hline Fishes & 34.23 & 32.42 & 64 \\
\hline Coleoptera & 5.51 & 5.15 & 1.63 \\
\hline Diptera & 1.99 & 1.02 & 0.12 \\
\hline Hymenoptera & 2.70 & 0.42 & 0.07 \\
\hline
\end{tabular}


Food Habits of Schilbe Intermedius, Rüppel, 1832 (Siluriformes: Schilbeidae) of Right Bank of Pool Malebo(Congo River)

\begin{tabular}{|c|c|c|c|}
\hline Heteroptera & 0.23 & 0.08 & 0.00 \\
\hline Lepidoptera & 0.12 & 0.09 & 0.00 \\
\hline Odonata & 0.47 & 0.48 & 0.01 \\
\hline Orthoptera & 0.35 & 0.04 & 0.00 \\
\hline Coleoptera larvaes & 2.34 & 0.91 & 2.35 \\
\hline Diptera larvaes & 7.85 & 5.21 & 1.62 \\
\hline Ephemeroptera larvaes & 8.79 & 3.21 & 0.26 \\
\hline Trichoptera larvaes & 1.88 & 2.43 & 6.99 \\
\hline Unidentified insects & 13.25 & 9.18 & 0.00 \\
\hline Arachnids Spiders & 0.12 & 0.04 & 0.02 \\
\hline CrustaceansShrimps & 1.64 & 0.26 & 0.00 \\
\hline Nematodes unidentified & 0.12 & 0.00 & 0.53 \\
\hline Annelida unidentified & 1.76 & 5.28 & 0.06 \\
\hline Myriapoda unidentified & 1.17 & 0.94 & 10.48 \\
\hline Planaria unidentified & 0.59 & 0.13 & 0.00 \\
\hline Plants debris & 13.60 & 13.40 & 0.25 \\
\hline Algaes & 0.35 & 0.01 & 11.63 \\
\hline Grains of sand & 8.44 & 0.52 & 18.75 \\
\hline
\end{tabular}

\subsection{Seasonal Variation of Trophic Structures}

Overall, the table 3 shows that theinsects larvaes were important preys in the rainy season with a preponderance index of $43 \%$ and become secondary preys in the dry season (11\%). The fishes had the same profile wherethey are important preys with a preponderance index of $36 \%$ in the rainy season and an index of $11 \%$ in the dry season (Table 4). On the other hand, insects that are accessory preys (1\%) become important preys in the dry season (36\%); unidentified preys are also accessory preys in the rainy season (7\%) and important preys in the dry season (37\%). Plants debris were accessory preys during the rainy season (12\%) and in the dry season (5\%). The $\alpha$ index is equal to 0.35 , which indicates a significant difference in diet according to the season. Another study (35) states that the stomach contents of this species vary with the season, with increasing rainfall, S. intermedius, which normally feeds fishes (preys that require effort for capture, consumes insects that have become more readily available. In contrary, during rainy season in one station of the Agnébi River,insects are the main preys in the diet of S. intermedius(14). Changes in diet are closely linked to the availability of preys.Insects reproduction occur during the rainy season, which explains their dominance in the supply Schilbe studied at this time (36). This explains the strong preponderance of insect larvae in the rainy season.Also, the eclectic trend confirmed by (15) explains the abundance of insects in the diet of S. intermediusespecially during the rainy season because the headwaters flowing floods inundate the surrounding vegetation and make available to fish a large number ofinsects trapped by the water. Similarly, thanks to the rain, insects and other invertebrates drowning and would be easily accessible prey for Schilbe intermedius. This explains in part the amount of food present in the stomachs is higher during the rainy season than in the dry season. In the dry season, insects are the main preys in the diet of S. intermediusin the headwaters of the Agnébi (14).

Table3. Composition of the dominant items in the diet of Schilbe intermedius in Pool Malebo according to season (Ip)

\begin{tabular}{|c|c|c|}
\hline Preys & Rainy season (Ip) & Dry season (Ip) \\
\hline Fishes (\%) & 36 & 11 \\
\hline Insects (\%) & 1 & 36 \\
\hline Insects larvaes (\%) & 43 & 11 \\
\hline Plants debris (\%) & 12 & 5 \\
\hline
\end{tabular}

The affinity of preys consumed between the two seasons dendrogram showed discrimination regime between the two seasons (Figure 5). Three groups of preys are discriminated, preys of high consumption (insect and insect larvaes) forming group 1 and group 3 (fishes and plant debris), the low consumption form group 2 (nematodes, annelids, algaes, myriapodes, planarias, spiders, crustacaes, unidentified preys et grains of sand). 
Food Habits of Schilbe Intermedius, Rüppel, 1832 (Siluriformes: Schilbeidae) of Right Bank of Pool Malebo(Congo River)

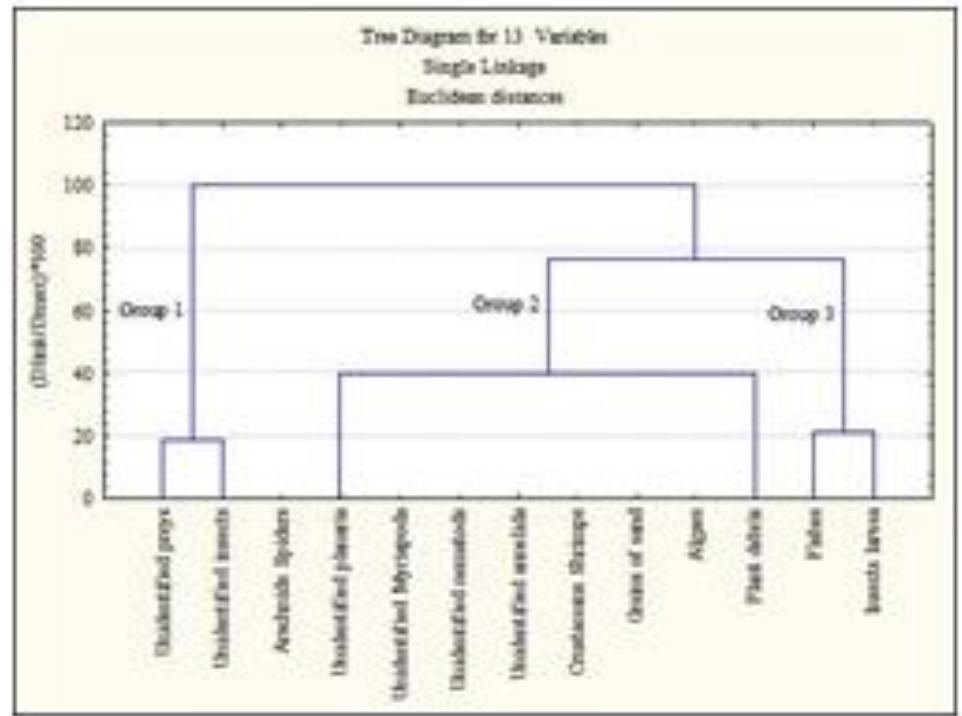

Figur5. Affinity dendrogram of different food items according to season

\subsection{Spatialvariation of Trophic Structures}

In Kintélé, fishes were major preys in S. intermedius; their preponderance index is $73 \%$ (Table 4). Plants debris $(8.5 \%)$, unidentified insects $(9 \%)$, Ephemeroptera larvaes $(6 \%)$ and other preys $(1.41 \%)$ are accessory preys. In Chacona, fishesrepresent also the main preys, the preponderance index was $65 \%$. Plants debris is secondary preys with a preponderance index of $19.6 \%$, unidentified insects are accessory preys with an index of $10 \%$ (Table 4). Ephemeroptera larvaes $(1.7 \%)$, unidentified preys $(1.4 \%)$ and beetles $(1 \%)$ and other preys are also accessory preys. In Port Leon, fishes remained main preys with a preponderance index of $68 \%$, followed by plants debris, unidentified insects and Diptera larvaes $(9 \%)$, other preys $(1.7 \%)$, unidentified preys $(1.6 \%)$ and spiders $(1 \%)$ which represent accessory preys (Table 4).

Table4. Composition of the dominant items in the diet of Schilbe intermedius in Pool Malebo according to station (Ip)

\begin{tabular}{|c|c|c|c|c|}
\hline \multicolumn{2}{|r|}{ Preys } & Kintélé & Chacona & Port Léon \\
\hline Vertébrés & Fishes & 72.84 & 65.36 & 68.21 \\
\hline \multirow{12}{*}{ Insects } & Coleoptera & 0.51 & 1.02 & 0.42 \\
\hline & Diptera & 0.00 & 0.02 & 0.27 \\
\hline & Hymenoptera & 0.03 & 0.06 & 0.13 \\
\hline & Heteroptera & 0.00 & 0.00 & 0.00 \\
\hline & Lepidoptera & 0.00 & 0.00 & 0.00 \\
\hline & Odonata & 0.00 & 0.00 & 0.04 \\
\hline & Orthoptera & 0.01 & 0.00 & 0.00 \\
\hline & Coleoptera larveas & 0.01 & 0.01 & 0.11 \\
\hline & Diptera larveas & 0.11 & 0.48 & 8.58 \\
\hline & Ephemeroptera larveas & 6.02 & 1.72 & 0.69 \\
\hline & Trichoptera larveas & 0.79 & 0.01 & 0.07 \\
\hline & Unidentified insects & 8.50 & 10.24 & 8.79 \\
\hline Arachnids & Spiders & 0.00 & 0.01 & 0.00 \\
\hline Crustaceans & Shrimps & 0.03 & 0.00 & 0.04 \\
\hline Nematodes & Unidentified & 0.00 & 0.00 & 0.00 \\
\hline Annelida & Unidentified & 0.45 & 0.00 & 1.21 \\
\hline Myriapoda & Unidentified & 0.00 & 0.00 & 0.26 \\
\hline Planaria & Unidentified & 0.00 & 0.00 & 0.02 \\
\hline Macrophytes & Plants debris & 9.26 & 19.62 & 9.50 \\
\hline \multirow[b]{3}{*}{ Others preys } & Algaes & 0.00 & 0.00 & 0.00 \\
\hline & Unidentified preys & 0.86 & 1.41 & 1.59 \\
\hline & Grains of sand & 0.58 & 0.04 & 0.07 \\
\hline
\end{tabular}

Among fishes, insects and plants debris are most consumed in the three stations with different preponderance index values (Table 5). 
Food Habits of Schilbe Intermedius, Rüppel, 1832 (Siluriformes: Schilbeidae) of Right Bank of Pool Malebo(Congo River)

Table5. Composition of the dominant items in the diet of Schilbe intermedius in Pool Malebo according to station (Ip)

\begin{tabular}{|c|c|c|c|}
\hline Preys & Kintélé & Chacona & Port Léon \\
\hline Fishes & 72.84 & 65.36 & 68.21 \\
\hline Insects & 15.98 & 13.56 & 19.1 \\
\hline Plant debris & 9.26 & 19.62 & 9.50 \\
\hline
\end{tabular}

The affinity dendrogram below is based on the different preponderance index of prey consumed by $\mathrm{S}$. intermedius recorded at the three stations. The results show that the stations constitute two groups, the first of which is formed by the Chacona station whose trophic spectrum is different from that of the two others. The second group corresponds to the two stations Kintele and Port Leon which present similarities of the trophic spectrum (figure 6).

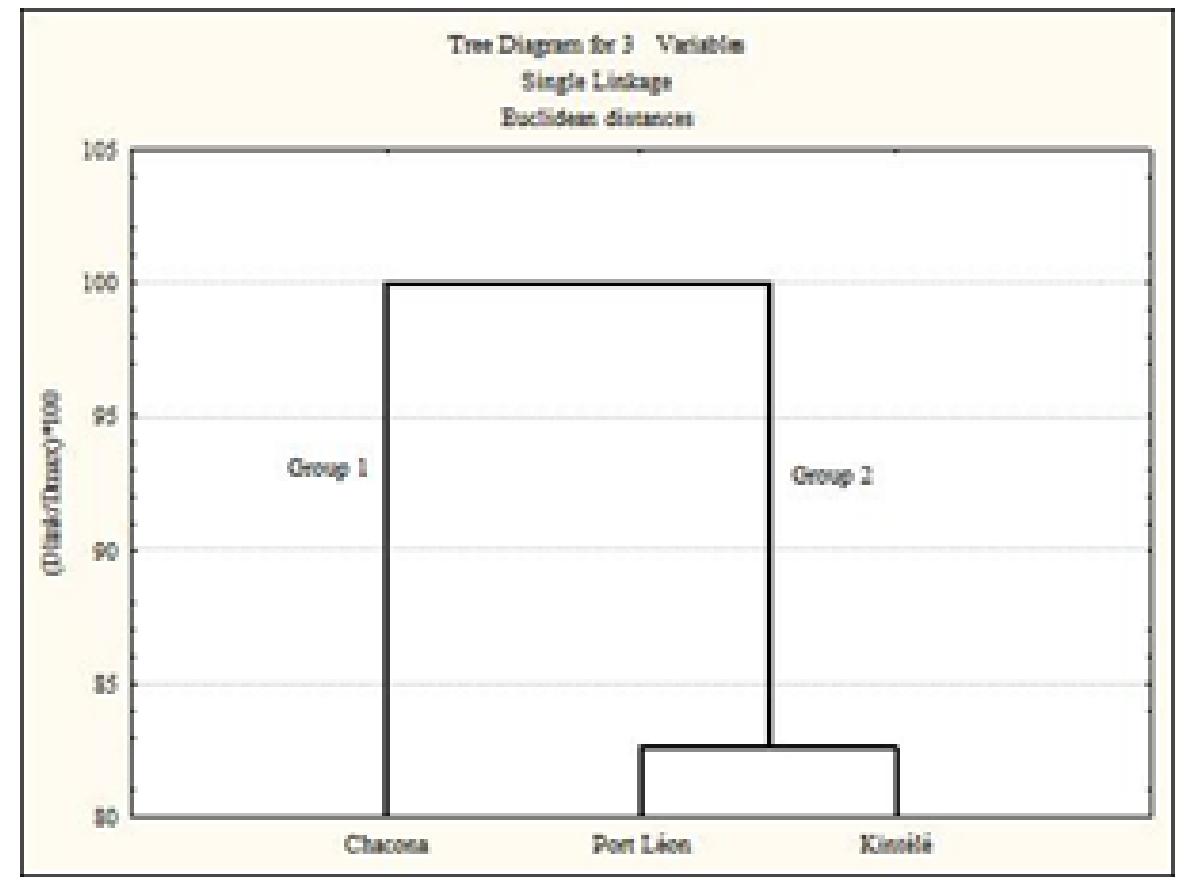

Figure6. Affinity Dendrogram of preponderance index of preys consumed by S. intermedius according to the station

\subsection{Variation of Trophic Structures of S. Intermedius According To Size}

Examination of the trophic structures of all individuals of S. intermedius showed that overall fish and invertebrates have the highest occurrences (Figures 6 and 7). The fishes are most consumed by classes 2, 3, 4, 5 and 6, the occurrences decrease from class 7. The low consumption of invertebrates observed in classes size 1 and $2(1 \%)$, which reaches the maximum with class 3(12\%) and decreases up to $5 \%$ in class 7 . The occurrences are less than $5 \%$ for the last three classes. Plants debris and other preys are the least consumed with $4 \%$ for classes 4 and 6 ; in class 5 , the occurrence is $3 \%$, the rest of the classes have occurrences between $1 \%$ and $2 \%$. The trophic spectrum differs according to size class, so that class 1-2 is mainly entomophagous. This entomophagy decreases as the specimenssize increases. The fishes are the main preys of all specimens from size class 3 (43.74 -53.3 mm).(18) has shown that the diet of young Schilbe that is entomophagous becomes ichthyophagous in larger individuals. (31) found that lake Chad specimenswitch size is between 210 and 230 mm consume more fishes $(66.2 \%$ by volume), for an occurrence of $39.3 \%$.(19) show that S. intermedius has an ontogenetic diet where young fishes have greater selectivity for aquatic macroinvertebrates, while larger fishes are more piscivorous, which is consistent with observations of (37), (16) and (38). Therefore, S. intermedius is not simply an opportunist, generalized insectivore and piscivorous predator (17), but is rather an opportunistic, widespread insectivore in small-sized juveniles that turn into a relatively more specialized piscivorous predator in older specimens of larger size. Concerning the variation in the diet according to the size, Schilbe intermediushas a tendency to become more pronounced with piscivory that size. This result confirms results of(9) in which the upper part of the Ogun River in Nigeria, shows that juvenile S. intermediushave a tendency to piscivory with 
Food Habits of Schilbe Intermedius, Rüppel, 1832 (Siluriformes: Schilbeidae) of Right Bank of Pool Malebo(Congo River)

increasing predator size. (15) Showed that genus Schilbe is ichthyophagous and food trend that increases with the age of the specimens.

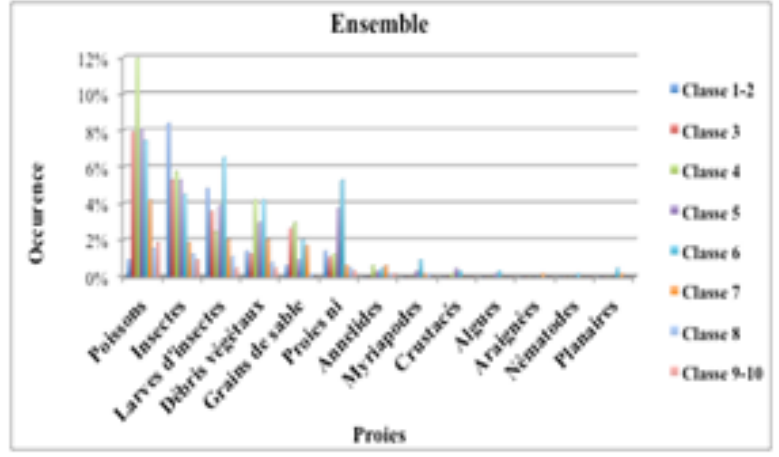

Figure 6: Global trophic spectrum of preys consumed by $S$. intermedius according to the size

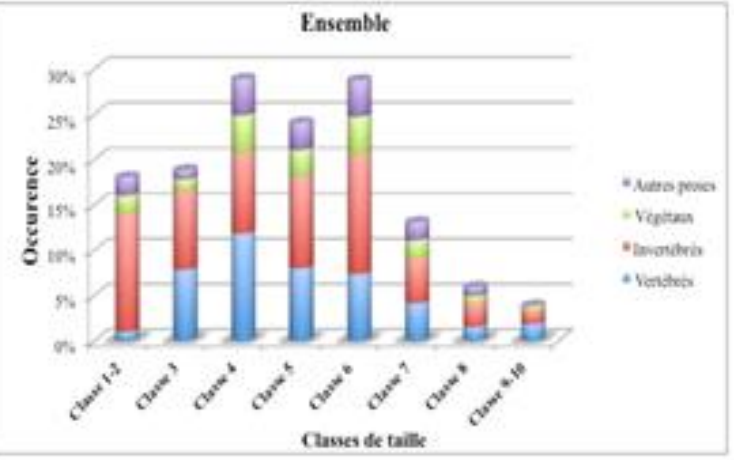

Figure 7: Global trophic spectrum of preys groups consumed by $S$. intermedius according to the size

The affinity dendrogram of the global trophic spectrum shows that specimensof S. intermediusform two groups of classes size (Figure 8). Group 1 is formed by the majority of classes: class 10, class 9, class 8 , class 7 , class 4 , class 5 , class 6 , class 3 . This group is divided into 3 subgroups, the first subgroup is formed by class 10 , class 9 and class 8 ; the second subgroup is formed by class 4 ; the third subgroup has the classes 6, 5 and 3.The subgroup 4 has only the class 1-2.

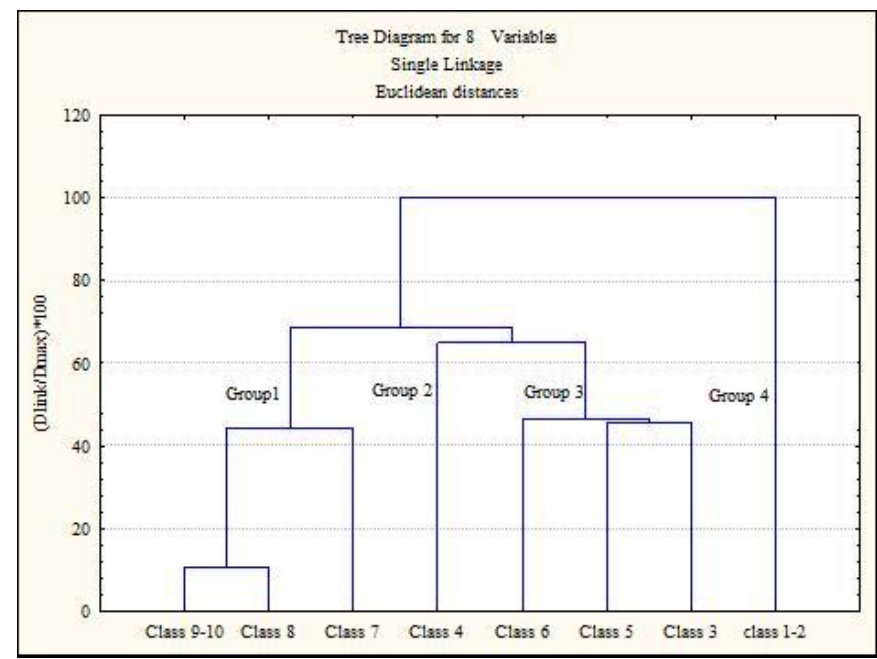

Figure8. Dendrogram of affinity of the global trophic spectrum of S. intermedius according to the size

\section{CONCLuSion}

The trophic structures of Schilbe intermedius were composed of fishes (34\%), followed by plants debris $(14 \%)$, unidentified insects (13\%), unidentified preys $(11 \%)$, trichoptera larvaes, grains of sand, coleoptera larvaes $(8 \%)$ and diptera $(6 \%)$. On the whole, fishes are the main preys consumed by Schilbe intermedius with a preponderance index of $64 \%$. Fishes are major preys species consumed by S. intermedius in Kintele station (Ip $=73 \%)$, Chacona station $(\mathrm{Ip}=65 \%)$ and Port Léon station $(\mathrm{Ip}=$ $68 \%$ ). The comparison of the preponderances indicates that there is no difference between the stations. Small specimens are entomophagous, we note theappearance of ichthyophagousspecimens with a standard length greater than or equal to $43.7 \mathrm{~mm}$.

\section{REFERENCES}

[1] Bradaï M.N. and Bouain A., Régime alimentaire de Scorpaena porcuset de S. scrofa (Teleostei, Scorpaenidaei du golfe de Gabès, Tunis. Cybium, 14 (3): 207-216.(1990).

[2] Rosecchi E. and Nouaze Y., Comparaison de cinq indices utilisés dans l'analyse des contenus stomacaux. Revue des Travaux de l'Institut des Pêches Maritimes 49, 111-123 (1987).

[3] Koné T., Teugels G. G., N'douba V., gooré bi G. and Kouamélan E. P. Premières données sur l'inventaire et la distribution de l'ichtyofaune d'un petit bassin côtier ouest africain: Rivière go (côte d'ivoire). Annales Université d'Abidjan., sér. E (Ecologie), 8(1):77-121. (2003). 
[4] Teugels G. G., Lévêque C., Paugy D. and Traore K., Etat des connaissances sur la faune ichtyologique des bassins côtiers de Côte d'Ivoire et du Ghana. Revue Hydrobiologie tropicale, 21 (3) : 221-237 (1988).

[5] Mady-Goma Dirat I., Mikia M., Tsoumou A., Vouidibio J. and Pandare D., Study of ichtyofauna biodiversity of rigth bank of Pool Malebo (Congo River).Res. J. Animal, Veterinary and Fishery Sci. 1(10), 23-25, (2013).

[6] Teugels, G. G., Taxonomy, phylogeny and biogeography of catfishes (Ostariophysi, Siluroidei): an overview. Legendre, M. et Proteau, J. P., (Eds.) ORSTOM, CIRAD, Aquat. living Resour., 9, suppl. : 9-34 (1996).

[7] Paugy, D., Leveque, C. and Teugels, G. G. The Fresh and Brackishwater Fishes of West Africa, Vol. I, IRD Editions. Collection Faune et Flore tropicales 40, Paris, 457pp.(2003).

[8] Paugy D., Ecologie des poissons tropicaux d'un cours d'eau temporaire Baoulé, haut bassin du Sénégal au Mali : adaptation au milieu et plasticité du régime alimentaire. Rev. Hydrobiol. trop., 27 : 157-172. (1994).

[9] Adebisi, A. A., Analysis of the stomach contents of the piscivorous fishes of the upper Ogun River in Nigeria. Hydrobiologia, 79 : 167-177 (1981).

[10] Ayoade A., Fagade S. and Adebisi A., Diet and dietary habits of the fish Schilbe mystus (Siluriformes: Schilbeidae) in two artificial lakes in Southwestern Nigeria. Rev. Biol. Trop. (Int. J. Trop. Biol. ISSN0034-7744) 56 (4): 000-000 (2008).

[11] Blache J., Les poissons du bassin du Tchad et du bassin adjacent du Mayo Kebbi. Etude systématique et biologique. ORSTOM Paris, 482 p. (1964).

[12] Daget, J. and iltis, A., Poissons de Côte d'Ivoire. (Eaux douces et saumâtres). Mém. Inst. Fr. Afr. Noire. IFAN, 74, 385 p. (1965).

[13] Doumbia L., Variations spatio-temporelles des peuplements et stratégies alimentaires de deux poissonschats africains: Schilbe mandibularis (Günther, 1867) et Schilbe intermedius Rüppell, 1832. (Bassins Bia et Agnébi ; Côte d'Ivoire). Thèse unique de doctorat de l'Université d'Abobo-Adjamé, Côte d'Ivoire, 188 p. (2004).

[14] Doumbia L., N'guessan Yao S., Ouattara A. and Gourène G., Diet of Schilbe intermedius Rüppell, 1832 in a coastal West African basin, Agnébi River in Côte d'Ivoire International Journal of Engineering and Technical Research 2(1), (2014).

[15] Lauzanne L., Les habitudes alimentaires des poissons d'eau douce africains. In: Lévêque C., Bruton M.N. \& Ssentongo G.W., Eds. Biologie et écologie des poissons d'eau douce africains. Paris, France: ORSTOM., pp 221-242 (1988).

[16] Merron G. S. and Bruton, M. N., The ecology and management of the fishes of the Okavango delta, Botswana, with special reference to the role of the seasonal flood, Investigational Report No 29. Grahamstown, South Africa. J.L.B. Smith Institute of Ichthyology. (1988).

[17] Merron G. S., The ecology and management of the fishes of the Okavango Delta, Botswana, with particular reference to the role of the seasonal flood. PhD dissertation. Rhodes University, Grahamstown, South Africa. (1991).

[18] Mok M., Biométrie et biologie des Schilbe (Pisces, Siluriformes) du bassin tchadien. IIe partie. Biologie comparée des deux espèces. Cah. Orstom, sér. Hydrobiol., 9(1), 33-60 (1975).

[19] Mosepele K., Mosepele B. and Williams L., Preliminary Assessment of the Feeding Ecology of Silver Catfish (Schilbe intermedius, Ruppel, 1832) in a Seasonal Floodplain of the Okavango Delta. Botswana Notes \& Records Vol 37. (2006).

[20] Okon A. O., Food and feeding habits of Schilbe intermedius in lower Cross River, Nigeria World Journal of Applied Science and Technology, 5 (2): 191-198 (2013).

[21] Olatunde A.A., Sex, reproductive cycle and variations in the fecundity of the family Schilbeidae (Osteichthyes: Siluriformes) in Lake Kainji, Nigeria. Hydrobiologa 57, 125-142 (1978).

[22] Reynolds D.J., Biology of the small pelagic fishes in the New Volta Lake in Ghana. Part III: sex and reproduction. Hydrobiologia 45, 489-508 (1974).

[23] Salako O., Contribution à l'étude de l'écologie et de la biologie des espèces de poisson du genre Schilbe (Schilbeidae) dans la vallée de l'Ouémé: habitat, alimentation, croissance et reproduction. Mémoire de fin d'études, Université Nationale du Bénin, Bénin. (1999).

[24] Kouamélan E.P., Teugels G.G., Gourène G., Thys Van Den Audenaerde D.F.E. and Ollevier F., Habitudes alimentaires de Mormyropsanguillö̈des (Mormyridae) en milieux lacustre et fluvial d'un bassin ouest africain. Cybium24, 67-79 (2000).

[25] Hynes H.B.N., The food of fresh water sticklebacks (Gasterosteus aculeatus and Pygosteus pungitius) with a review of methods used in studies of the food of fishes. J. Anim. Ecol. 19, 36-58 (1950). 
Food Habits of Schilbe Intermedius, Rüppel, 1832 (Siluriformes: Schilbeidae) of Right Bank of Pool Malebo(Congo River)

[26] Natarajan A.V. and Jhingran A.G., Index of preponderance - a method of grading the food elements in the stomach analysis of fishes. IndianJournal of Fisheries 8, 54-59(1961).

[27] Schoener T.W., Non-synchronous spatial overlap of lizards in patchy habitats. Ecology 51, 408-418 (1970).

[28] Werner E.E. and Hall D.J., Competition and habitat shift in two sunfishes (Centrarchidae). Ecology58, 869-976 (1977).

[29] Kouamélan, E. P., Gourène, G., Teugels, G. G., N'douba, V. and Thys Van Den Audenaerde, D. F. E., Diversité morphologique du tube digestif chez 39 espèces de poissons africains et relation avec la classification ichtyologique. Journal of African Zoology, 111: 109-119.(1997).

[30] Carey, T.G., Hydrological survey of the Kafue floodplain. Fish. Res. Bull. Zambia. 5:245-295. (1971).

[31] Lauzanne L., Régimes alimentaires et relations trophiques des poissons du lac Tchad. Cah. ORSTOM., sér. Hydrobiologie, 10, 267-310 (1976).

[32] Bailey R.G., Guide to the fishes of the River Nile in the Republic of the Sudan. J. Nat. Hist. 28:937- 970. (1994).

[33] Skelton P., A complete guide to freshwater fishes of southern Africa. Cape Town. Struik Publishers. 2nd edition (2001).

[34] Welcomme, R.L., Inland fisheries ; Ecology and Management. Oxford: Blackwell Science. (2001).

[35] Teferra G., Feledi B. and Motlhabane D., The effects of rainfall on the composition and quality of food ingested by two species of fishes, Schilbe intermedius and Oreochromis mossambicus, in Gaborone dam. Botswana Notes and Records, 35, 179-186 (2003).

[36] Dietoa Y. M., Entomofaune et stratégies alimentaires des poissons du genre Brycinus (Characidae) en milieux fluviatiles et lacustres (Bassins Bia et Agnébi ; Côte d'Ivoire). Thèse unique de Doctorat de l'Université d'Abobo-Adjamé, Côte d'Ivoire, 261p. (2003).

[37] Van Der Waal B.C.W., Aspects of the biology of larger fish species of Lake Liambezi, Caprivi, South West Africa.Madoqua, 14(2), 101-144 (1985).

[38] Witte F. and De Winter W., Appendix II. Biology of the major fish species of Lake Victoria. pp. $301-320$. In: Witte F. \&Van Densen W.L.T. (eds.). Fish Stocks and Fisheries of Lake Victoria.A Handbook for Field Observations. Samara Publishing Limited, Dyfed, Great Britain. (1995).

Citation: Mady-Goma Dirat I., et al., "Research Laboratory of Animal Biology and Ecology, ENS, University Marien Ngouabi, PoBox 69 ", International Journal of Research Studies in Zoology, vol. 5, no. 1, p. 1-10, 2019. DOI: http://dx.doi.org/10.20431/2454-941X.0501001

Copyright: (C) 2019 Authors. This is an open-access article distributed under the terms of the Creative Commons Attribution License, which permits unrestricted use, distribution, and reproduction in any medium, provided the original author and source are credited. 